CASSOWARY 3 (1): 45 - 60

ISSN : 2614-8900

E-ISSN : 2622-6545

CProgram Pascasarjana Universitas Papua, https://pasca.unipa.ac.id/

\title{
Strategi pengembangan ternak Sapi Potong di Kabupaten Pegunungan Arfak, Provinsi Papua Barat
}

\author{
Strategy for beef cattle development in Arfak Mountain Regency, West \\ Papua Province
}

Jan Pieter Rumpaidus, Mohamad Jen Wajo dan Stepanus Pakage

Program Studi Ilmu Peternakan, Program Pascasarjana, Universitas Papua

Jalan Gunung Salju, Amban, Manokwari, 98314, Indonesia

*Email: m.wajo@unipa.ac.id

\begin{abstract}
Arfak Mountains Regency has potential resources for agriculture, plantations, livestock, fisheries and forestry. Arfak Mountains Regency is very potential for the development of beef cattle, but many obstacles are faced. So it is necessary to do research to find out the strengths, weaknesses, opportunities and threats or strategies for developing beef cattle in the Arfak Mountains District, West Papua Province. This study aims to identify the factors that influence the development of beef cattle and develop suitable alternative strategies to be applied in the development of beef cattle in the Arfak Mountains District. The alternative strategy that can be done is to strengthen capital in order to compete, expand the market share of beef cattle and improve the quality of beef cattle products.
\end{abstract}

Keywords: development strategies, alternative strategies, beef cattle

ABSTRAK: Kabupaten Pegunungan Arfak memiliki sumberdaya yang potensial baik pertanian, perkebunan, peternakan, perikanan, maupun kehutanan. Kabupaten Pegunungan Arfak sangat potensial untuk pengembangan ternak sapi potong, namun banyak kendala yang dihadapi. Sehingga perlu dilakukan penelitian untuk mengetahui strenght (kekuatan), weakness (kelemahan), opportunity (peluang) dan Threat (ancaman atau hambatan) atau strategi pengembangan ternak sapi potong di Kabupaten Pegunungan Arfak, Provinsi Papua Barat. Penelitian ini bertujuan untuk mengidentifikasi faktor-faktor yang mempengaruhi pengembangan ternak sapi potong dan menyusun alternatif strategi yang sesuai untuk diterapkan dalam pengembangan ternak sapi potong di Kabupaten Pegunungan Arfak. Alternatif strategi yang dapat dilakukan adalah memperkuat permodalan agar dapat bersaing, memperluas pangsa pasar sapi potong dan meningkatkan kualitas hasil ternak sapi potong.

Kata kunci: strategi pengembangan, alternatif strategi, sapi potong

\section{PENDAHULUAN}

Konsumsi protein hewani di Indonesia saat ini masih di bawah standar gizi nasional. Konsumsi protein hewani saat ini sebesar 4,19 gram/kapita/hari, atau setara dengan 5,25 $\mathrm{kg}$ daging, 3,5 $\mathrm{kg}$ telur, dan susu 
5,5 kg/kapita/tahun. Sedangkan standar konsumsi protein hewani yang ditetapkan FAO adalah 6 gram/kapita /hari atau setara dengan 10,1 kg daging, $3,5 \mathrm{~kg}$ telur, dan susu 46,4 kg/kapita /tahun (Daryanto, 2014). Kebutuhan permintaan daging secara nasional semakin meningkat seiring dengan laju pertumbuhan ekonomi yang semakin baik, pembangunan pendidikan yang lebih maju, kesadaran kebutuhan nutrisi asal ternak semakin meningkat, sehingga menyebabkan pemotongan sapi dari berbagai bangsa juga semakin meningkat untuk memenuhi kebutuhan tersebut (Suswono, 2009).

Ternak sapi potong di Indonesia merupakan salah satu penghasil sumber pangan yang sangat dibutuhkan yaitu berupa daging. Namun produktivitasnya masih sangat memprihatinkan karena jumlahnya masih jauh dari target yang diperlukan konsumen. Faktor yang menyebabkan jumlah produksi daging sapi masih rendah antara lain populasi dan produktivitas sapi masih rendah. Produksi daging sapi di Indonesia hingga tahun 2015 mencapai 506.660 ton, sedangkan populasi sapi potong di Indonesia hingga tahun 2015 hanya mencapai 15.419.720 ekor (Ditjen PKH, 2015). Untuk mengatasi masalah tersebut, upaya - upaya yang dapat dilakukan antara lain impor sapi bakalan, daging beku sapi dan kerbau, peningkatan produktivitas berbagai usaha peternakan, program peningkatan swasembada daging sapi potong, program pengembangan plasma nutfah lokal dan pemanfaatan satwa liar penghasil daging.

Provinsi Papua Barat memiliki kondisi lingkungan yang baik untuk perkembangan ternak sapi potong dan juga memiliki potensi ketersediaan lahan dan pakan yang cukup. Suprihadi (2001), mengatakan bahwa lahan seluas 75.000 ha yang merupakan padang penggembalaan di Distrik Bomberay (Fakfak), Kebar (Tambrauw) dan Salawati (Sorong) disiapkan untuk pembudidayaan sapi potong dengan sistim ranch atau program bumi sejuta ranch di Provinsi Papua Barat. Disamping itu pula memiliki ketersediaan lahan pertanian seluas 11,263 ha dan lahan perkebunan kelapa sawit seluas 38,98 ribu ha dan daerah kantong ternak Sapi Bali lainnya seperti daerah ex transmigrasi dan daerah pemekaran lainnya.

Kabupaten Pegunungan Arfak secara definitif terbentuk berdasarkan Undang-Undang Nomor 24 Tahun 2012 dan memiliki luas wilayah $\pm 2.773,74$ $\mathrm{km}^{2}$, dengan rincian : hutan belantara 288.015 Ha, Danau dan Sungai 4.626,4 Ha, Pertanian Lahan Kering dan Semak 2.028,2 Ha, Pemukiman dan Kebun 2.611,3 Ha, Lahan Kering Tidak Produktif 28.490,6 Ha dan Tanah Terbuka 18.703,4 Ha. Kabupaten Pegunungan Arfak memiliki sumberdaya yang potensial baik pertanian, perkebunan, peternakan, perikanan, maupun kehutanan. Berbagai komoditi pertanian antara lain tanaman hortikultura (wortel, daun bawang, bawang putih, bawang merah, kentang, petsai, kubis, seledri, jeruk manis, nenas, dan markisa juga bunga anggrek, krisan dan gladiol); tanaman pangan (ubi jalar, ubi kayu dan jagung); tanaman perkebunan (kopi); peternakan (sapi potong dan babi); perikanan (ikan nila, ikan mas, dan ikan mujair), dan tanaman kehutanan (gaharu dan matoa). Ternak sapi pertama kali dikenalkan sejak adanya bantuan ternak sapi bagi masayarakat asli Arfak. Jenis ternak sapi yang diberikan kepada masyarakat adalah sapi bali (Bos sondaicus).

Target pembangunan yang hendak dicapai di Kabupaten Pegunungan Arfak adalah penyebaran dan pemerataan pertumbuhan yang 
sesuai dengan potensi lokal dan daya dukung lingkungan. Berkaitan dengan ini upaya kerja keras sangat diperlukan dalam percepatan pembangunan agar target pembangunan dapat benar-benar dicapai sehingga kemajuan pembangunan menjadi sejajar dengan kabupaten lain yang ada di Provinsi Papua Barat ini. Berkaitan dengan itu, pembangunan peternakan sebagai salah satu sub sektor merupakan bagian integral pembangunan pertanian. Ternyata pembangunan peternakan memerlukan sebuah desain program yang matang, mulai dari perencanaan, pelaksanaan, pemantauan (monitoring), sampai terhadap evaluasi.

Kabupaten Pegunungan Arfak sangat potensial untuk pengembangan ternak sapi potong, namun banyak kendala yang dihadapi. Untuk itu perlu dilakukan penelitian untuk mengetahui strenght (kekuatan), weakness (kelemahan), opportunity (peluang) dan Threat (ancaman atau hambatan) atau strategi pengembangan ternak sapi potong di Kabupaten Pegunungan Arfak, Provinsi Papua Barat. Penelitian ini bertujuan untuk mengidentifikasi faktor-faktor yang mempengaruhi pengembangan ternak sapi potong dan menyusun alternatif strategi yang sesuai untuk diterapkan dalam pengembangan ternak sapi potong di Kabupaten Pegunungan Arfak. Kiranya hasil penelitian ini dapat menjadi acuan bagi pemerintah dan peternak dalam usaha pengembangan ternak sapi potong di Kabupaten Pegunungan Arfak, Provinsi Papua Barat.

\section{METODE PENELITIAN}

Penelitian ini dilaksanakan di Kabupaten Pegunungan Arfak dengan waktu penelitian selama 2 (dua) bulan, yaitu dari Bulan Juli sampai September 2018.

Metode yang digunakan dalam penelitian ini adalah metode deskriptif analitik yang bersifat studi kasus (Sugiyono, 2003), dengan teknik survey, observasi, wawancara dan partisipatory. Data primer adalah data yang diperoleh langsung di Kabupaten Pegunungan Arfak, baik melalui wawancara maupun observasi mengenai pengembangan ternak sapi potong, serta dokumentasi guna mendukung hasil penelitian. Sedangkan data sekunder penelitian ini adalah data yang diperoleh dari beragam pustaka yang menunjang dan berhubungan dengan kajian. Data tersebut berupa laporan tahunan, jurnal, skripsi dan tesis yang berkaitan dengan penelitian ini.

Analisis data dalam kajian ini menggunakan pendekatan kualitatif pada prinsipnya berproses secara analisa deskripsi (content analysis). Secara umum sebenarnya proses analisa telah dimulai sejak peneliti menetapkan fokus permasalahan dan Kabupaten Pegunungan Arfak, kemudian menjadi intensif ketika turun ke lapangan. Data yang diperoleh dianalisis menggunakan analisis SWOT.

\section{HASIL DAN PEMBAHASAN}

Melalui pengamatan, wawancara dan studi pustaka yang dilakukan terhadap kegiatan dan berbagai upaya penanganan ternak sapi potong di Kabupaten Pegunungan Arfak, maka dapat diuraikan kondisi dan situasinya sebagai berikut:

\section{Faktor Internal}

Identifikasi faktor internal dilakukan untuk mengetahui kekuatan dan kelemahan yang dihadapi dalam pengembangan ternak sapi potong di Kabupaten Pegunungan Arfak Provinsi Papua Barat, seperti ditampilkan pada Tabel 1. 
Tabel 1. Faktor Internal

\begin{tabular}{|c|c|}
\hline Kekuatan (S) & Kelemahan (W) \\
\hline A. Ketersediaan lahan & $\begin{array}{l}\text { 1. Peruntukan lahan untuk kebutuhan lain } \\
\text { di luar subsektor peternakan }\end{array}$ \\
\hline $\begin{array}{l}\text { B. Terdapat padang } \\
\text { penggembalaan alami, } \\
\text { ketersediaan HMT dan limbah } \\
\text { pertanian/perkebunan yang } \\
\text { melimpah sebagai sumber } \\
\text { pakan }\end{array}$ & $\begin{array}{l}\text { 2. Pemanfaatan kepada ternak kurang, } \\
\text { belum dikelola secara profesional }\end{array}$ \\
\hline $\begin{array}{l}\text { C. Dinas Teknis dan Fasilitas } \\
\text { tersedia }\end{array}$ & $\begin{array}{l}\text { 3. Petugas kurang, regulasi teknis peternak } \\
\text { belum ada }\end{array}$ \\
\hline D. Minat masyarakat & $\begin{array}{l}\text { 4. Tingkat pengetahuan terbatas. Dan tidak } \\
\text { memiliki proses edukasi tentang } \\
\text { beternak sapi }\end{array}$ \\
\hline $\begin{array}{l}\text { E. Tersedia stok/pasokan daging } \\
\text { sapi }\end{array}$ & $\begin{array}{l}\text { 5. Konsumen terbatas, jalur tata niaga } \\
\text { masih terpusat di Kabupaten } \\
\text { Pegunungan Arfak saja, tidak ada } \\
\text { standar harga yang paten. }\end{array}$ \\
\hline
\end{tabular}

Sumber : Olahan Data Primer

Faktor internal sebagaimana Tabel 1 di atas menjadi poin penting yang perlu diketahui dan dipahami oleh pelaku usaha ternak sapi potong sehingga dapat dimanfaatkan secara maksimal dan diupayakan penanganan atau solusinya secara tepat dan benar demi eksistensi dan kontinuitas usaha ternak sapi potong di Kabupaten Pegunungan Arfak, yang dapat diuraikan sebagai berikut:

1. Kabupaten Pegunungan Arfak memiliki lahan yang luas sehingga masih banyak lahan kosong yang dapat dijadikan lokasi pengembangan ternak sapi potong. Sesungguhnya lahan bukan masalah bagi usaha peternakan oleh karena pada kondisi lahan yang buruk (tandus, lahan tidur, lahan dengan topografi yang tidak rata) sekali pun dan dengan luasan seadanya, akan tetapi jika dikelola (lahan, pakan dan pemeliharaan) dengan manajemen yang baik tentunya usaha peternakan dapat berlang- sung, bahkan bisa dimaksimalkan pengembangan usaha ternaknya, secara khusus ternak sapi potong. Hal ini sesuai dengan pendapat Abun et al (2008), yang menyatakan bahwa keberhasilan budidaya dipengaruhi oleh tiga faktor, yaitu genetik, pakan, dan manajemen. Pakan merupakan faktor terpenting dalam budidaya karena berpengaruh terhadap produksi, pertumbuhan, dan kondisi fisiologis ternak. Ketersediaan ternak dalam hal ini kontinuitas dipelihara kemudian dijual dipengaruhi oleh ketersediaan ternak induk yang pasti dengan genetik yang baik, karena dalam pembibitan ternak jumlah induk menentukan peningkatan atau penurunan populasi ternak.

2. Padang penggembalaan alami dan HMT serta limbah pertanian/perkebunan (padangan, rumput, leguminosae, limbah jagung, sayuran) di Kabupaten Pegunungan Arfak cukup melimpah. Berbagai rumput 
seperti rumput raja (Pennisetum purpuroides), rumput gajah (pennisetum purpureum), rumput irian (Shorgum sp), rumput mexico (Euchelena mexicana), rumput bede atau signal (Brachiaria decumbens) dan jenis rumput asli lainnya, juga berbagai leguminosae seperti Chyratro, Glyricidae, turi, lamtoro, kaliandra yang tumbuh secara alami dengan luasan dapat mencapai puluhan hingga ratusan hektar sangat cukup untuk pengembangan tenak sapi potong. Dengan sumber HMT yang melimpah untuk pemenuhan kebutuhan ternak sapi potong akan memungkinkan optimalnya produksi ternak sapi potong di Kabupaten Pegunungan Arfak.

3. Bidang peternakan dengan tenaga ahli dan berbagai program kerjanya, serta fasilitas pendukung peternakan seperti Balai Perbibitan dan Hijauan Pakan Ternak (BPHPT) juga Pusat Kesehatan Hewan (Puskeswan) sudah tersedia dan akan sangat berkontribusi bagi pengembangan ternak sapi potong di Kabupaten Pegunungan Arfak.

4. Minat yang tinggi dari masyarakat untuk menekuni peternakan sapi potong, yang dibuktikan dengan diusulkannya pengadaan ternak khususnya ternak sapi potong sebagai program prioritas pada saat musyawarah perencanaan pembangunan (musrenbang) tingkat distrik.

Faktor internal yang menunjukkan kelemahan dalam usaha pengembangan ternak sapi potong di Kabupaten Pegunungan Arfak Papua Barat antara lain :

1. Kabupaten Pegunungan Arfak sebagai kabupaten baru yang hampir sebagian wilayahnya merupakan kawasan lindung (83,82 \%), berakibat pada keterbatasan peng- gunaan lahan untuk pemanfaatan lain, dan menjadi rebutan bagi berbagai sektor terkait dengan perkembangan dan pembangunan baik infra struktur pemerintahan maupun umum bahkan pemukiman. Hal ini menjadi situasi yang dapat melemahkan upaya pengembangan sapi potong di Kabupaten Pegunungan Arfak.

2. Ketersediaan HMT (padangan dan rumput yang tumbuh alami) dan limbah pertanian/perkebunan untuk pengembangan tenak sapi potong sesungguhnya sangat cukup ketika dilihat keberadaannya di alam, namun pemanfaatannya bagi kebutuhan hidup ternak belum maksimal dilakukan, tetapi juga upaya pembudidayaan dan pengelolaan yang baik dengan pengaturan komposisi botanis maupun peningkatan kualitas pakan melalui aplikasi teknologi pakan kurang bahkan tidak dilakukan. Keadaan ini terjadi sebagai akibat tingkat pengetahuan peternak terbatas dan minim pengalaman beternak sapi.

3. Fasilitas pendukung peternakan seperti Balai Perbibitan dan Hijauan Pakan Ternak (BPHPT) juga Pusat Kesehatan Hewan (Puskeswan) tersedia, tetapi masih belum diaktifkan karena kurangnya petugas dan belum adanya tenaga medik dalam hal ini dokter hewan.

4. Sistem pemeliharaan ternak sapi potong yang dijalankan oleh peternak umunya secara sederhana saja, sebagai akibat dari tidak adanya pengalaman beternak yang dimiliki atau tidak adanya pengetahuan beternak oleh karena masyarakat Arfak atau Papua umumnya tidak mengenal budaya beternak sapi. Hal ini sangat berpengaruh dalam tingkat produktifitas ternak sapi potong, 
sebagaimana pendapat Wiyatna et al (2012), bahwa sapi-sapi dengan sistem pemeliharaan tradisional, dimana peternak melakukan usaha tersebut sebagai usaha sambilan, umumnya terkendala dengan rendahnya konsumsi pakan ternak dan keterbatasan fasilitas lahan ternak.

5. Pemasaran ternak sapi potong masih terbatas karena penjualan hanya dilakukan apabila ada permintaan untuk acara keluarga yang menyajikan daging sapi ataupun untuk pembayaran mas kawin dan denda adat. Hal ini yang mengakibatkan sehingga pemasaran ternak sapi potong terbatas di kalangan tertentu. Selain itu, transportasi jalan yang belum memadai serta jarak tempuh yang jauh dan informasi pasar yang kurang mengakibatkan pemasaran terbatas. Pasar menjadi salah satu faktor penting dalam usaha peternakan sapi potong karena tanpa pasar maka proses perdagangan produk tidak akan terjadi. Pemasaran sapi baik dalam bentuk hidup maupun daging dan kulit saat ini mempunyai peluang yang sangat bagus.

\section{Faktor Eksternal}

Identifikasi faktor eksternal dilakukan untuk mengetahui peluang dan ancaman yang dihadapi pengembangan ternak sapi potong di Kabupaten Pegunungan Arfak Provinsi Papua Barat. Berbagai Faktor eksternal yang diprediksi dapat berpengaruh terhadap pengembangan sapi potong di Kabupaten Pegunungan Arfak disajikan pada Tabel 2.

Tabel 2. Faktor Eksternal

\begin{tabular}{|c|c|}
\hline Peluang (O) & Ancaman (T) \\
\hline 1. Kebutuhan masyarakat akan sapi potong & 1. Fenomena teknologi \\
\hline 2. Daya tawar pembeli & 2. Persaingan antar peternak \\
\hline 3. Fenomena sosial budaya dan demografi & 3. Kondisi ekonomi masyarakat \\
\hline $\begin{array}{l}\text { 4. Pengembangan Kabupaten Pegunungan } \\
\text { Arfak sebagai daerah pariwisata }\end{array}$ & $\begin{array}{l}\text { 4. Masuknya stok daging sapi dari } \\
\text { luar Kabupaten Pegaf untuk } \\
\text { memenuhi kebutuhan } \\
\text { permintaan konsumen }\end{array}$ \\
\hline $\begin{array}{l}\text { 5. Terhubungannya berbagai kota di Papua } \\
\text { Barat dengan jalan trans Papua } \\
\text { membuka jalur tata niaga antar kota }\end{array}$ & 5. Permainan harga produk ternak \\
\hline
\end{tabular}

Sumber : Olahan Data Primer

Tabel 2 di atas menunjukkan faktor eksternal yang merupakan peluang yaitu:

1. Kebutuhan masyarakat akan sapi potong meningkat dengan adanya permintaan untuk acara keluarga yang menyajikan daging sapi ataupun untuk pembayaran mas kawin ataupun denda adat di Kabupaten Pegunungan Arfak, menjadikan usaha sapi potong ini sangat menjanjikan. Ke depannya usaha ternak sapi potong ini juga dapat membantu meningkatkan pendapatan masyarakat, bahkan menjadi salah satu solusi untuk mengatasi pengangguran. Usaha peternakan dapat memberikan keuntungan apabila diarahkan menjadi usaha yang bersifat komersial. 
2. Dengan masuknya pendatang dari luar Papua ke Kabupaten Pegunungan Arfak, maka akan menjadikan daya tawar ternak sapi potong semakin meningkat.

3. Fenomena sosial budaya dan demografi, fenomena tersebut menjadikan peluang usaha sapi potong di Kabupaten Pegunungan Arfak, semakin berkembangnya lingkungan dengan banyaknya pendatang mempengaruhi pandangan masyarakat lokal tentang kebutuhan sapi potong. Selain itu demografi masyarakat sekitar juga memungkinkan usaha ternak sapi potong di Kabupaten Pegunungan Arfak dapat berkembang.

4. Pengembangan Pariwisata sebagai salah satu ikon Kabupaten Pegunungan Arfak, memungkinkan berkembangannya usaha perhotelan, resto dan berbagai penyedia jasa penginapan dan jasa chatering yang tentunya membutuhkan stok daging sapi sebagai salah satu bahan baku menu makanannya bagi wisatawan menjadi peluang bagi pengembangan usaha sapi potong di Kab. Pegunungan Arfak

5. Pembangunan jalan Trans Papua Barat yang saat ini menjadi prioritas Pemda Papua Barat untuk menghubungkan berbagai kabupaten/kota di Papua Barat akan menjadikan Kabupaten Pegunungan Arfak sebagai salah satu kota transit dan memberikan kesempatan bagi jalur tata niaga antar kota dan ini berpeluang memberi kontribusi bagi perdagangan ternak sapi, yang akhirnya berdampak pada perkembangan usaha ternak sapi potong di Kab. Pegunungan Arfak

Faktor eksternal yang diduga menunjukkan ancaman yang diperoleh dalam usaha ternak sapi potong di Kab. Pegunungan Arfak antara lain :

1. Semakin berkembangnya teknologi dalam pengembangan ternak sapi potong dan juga teknologi dalam hal pemasaran ternak sapi potong menjadikan ancaman usaha sapi potong di Kabupaten Pegunungan Arfak dikarenakan akses di daerah sangat terbatas sehingga jaringan distribusi ternak sapi potong juga terbatas. Menurut Diwyanto (2008) keberhasilan suatu usaha peternakan ditentukan oleh perkembangan teknologi, baik aplikasi Inseminasi Buatan (IB) di Indonesia sudah sangat meluas, terutama pada sapi perah $(>90 \%)$ dan sapi potong. Secara intensif IB pada sapi perah mulai dilakukan tahun 1972 oleh lembaga Penelitian Peternakan Bogor. Sementara itu, IB pada sapi potong di Indonesia saat ini mungkin termasuk yang terbesar di Dunia. Hal ini antara lain langkanya pejantan di beberapa kawasan sentra produksi Sapi Potong.

2. Persaingan yang terjadi di antara peternak menjadikan ancaman dalam usaha ternak sapi potong, dimana usaha tersebut biasanya menjadikan kelompok-kelompok usaha yang memiliki modal yang kuat yang dapat menguasai pasar,

3. Kondisi ekonomi masyarakat sekitar yang tidak terlalu merata dan tidak terlalu besar dalam kebutuhan daging sapi potong menjadi ancaman dalam pemasaran ternak sapi potong di Kabupaten Pegunungan Arfak Papua. Selain itu kemampuan peternak dalam mengelola usahanya, seperti latar belakang pendidikan, ketrampilan, pengalaman berusaha dan kemauan untuk terus belajar adalah salah 
satu faktor penting ancaman dalam usaha ternak sapi potong.

4. Ketika Kab. Pegunungan Arfak mengalami perkembangan yang cukup pesat terutama pada aspek pariwisata, maka tuntutan terhadap ketersediaan bahan baku daging sapi untuk memenuhi kebutuhan konsumen menjadi tinggi dan dapat dipastikan apabila ketersediaan tidak mencukupi, akan ada upaya memasukan stok daging sapi dari wilayah lain di Papua atau pun dari luar Papua bahkan mungkin luar negeri dan menjadi ancaman bagi eksistensi pengembangan peternakan sapi potong di Kabupaten Pegunungan Arfak.

5. Adanya akses yang dapat menghubungkan antar kota di Papua Barat turut serta memberikan kemudahan bagi jalur tata niaga produk ternak sapi, namun ancaman yang kemudian dapat timbul adalah adanya kemungkinan permainan harga, apabila tidak tersedia regulasi yang mengaturnya, maka yang paling merasakan kerugian dari situasi ini adalah pelaku usaha peternakan sapi potong dan hal ini dapat menjadi ancaman bagi perkembangan usaha ternak sapi potong di Kabupaten Pegunungan Arfak.

Evaluasi terhadap pengaruh kekuatan dan kelemahan yang dimiliki (IFE) dalam upaya pengembangan ternak sapi potong di Kabupaten Pegunungan Arfak dengan berpedoman pada Matriks IFE sehingga diperoleh hasil sebagaimana Tabel 3 di bawah ini.

Tabel 3. Matriks IFE

\begin{tabular}{|c|c|c|c|}
\hline FAKTOR INTERNAL & Bobot & Rating & Skor \\
\hline \multicolumn{4}{|l|}{ Kekuatan } \\
\hline Ketersediaan lahan & 0.08 & 2.3 & 0.19 \\
\hline Terdapat padang penggembalaan alami, ketersediaan & & & \\
\hline $\begin{array}{l}\text { HMT dan limbah pertanian/perkebunan yang melimpah } \\
\text { sebagai sumber pakan }\end{array}$ & 0.09 & 2.4 & 0.21 \\
\hline Dinas Teknis dan Fasilitas tersedia & 0.08 & 2.2 & 0.18 \\
\hline Minat masyarakat & 0.08 & 2.2 & 0.17 \\
\hline Tersedia stok/pasokan daging sapi & 0.09 & 2.6 & 0.25 \\
\hline \multicolumn{4}{|l|}{ Kelemahan } \\
\hline $\begin{array}{l}\text { Peruntukan lahan untuk kebutuhan lain di luar subsektor } \\
\text { peternakan }\end{array}$ & 0.13 & 3.5 & 0.44 \\
\hline $\begin{array}{l}\text { Pemanfaatan kepada ternak kurang, belum dikelola secara } \\
\text { profesional }\end{array}$ & 0.11 & 3.1 & 0.35 \\
\hline Petugas kurang, regulasi teknis peternak belum ada & 0.11 & 3.0 & 0.34 \\
\hline $\begin{array}{l}\text { Tingkat pengetahuan terbatas. Dan tidak memiliki proses } \\
\text { edukasi tentang beternak sapi }\end{array}$ & 0.12 & 3.2 & 0.37 \\
\hline $\begin{array}{l}\text { Konsumen terbatas, jalur tata niaga masih terpusat di } \\
\text { Kabupaten Pegunungan Arfak saja, tidak ada standar } \\
\text { harga yang paten. }\end{array}$ & 0.11 & 3.0 & 0.34 \\
\hline & 1 & & 2,82 \\
\hline
\end{tabular}


Tabel 4. Matriks EFE

\begin{tabular}{lccc}
\hline \multicolumn{1}{c}{ FAKTOR EKSTERNAL } & Bobot & Rating & Skor \\
\hline Kebutuhan masyarakat akan sapi potong & 0.09 & 2.64 & 0.25 \\
Daya tawar pembeli & 0.10 & 2.92 & 0.30 \\
Fenomena sosial budaya dan demografi & 0.09 & 2.64 & 0.25 \\
$\begin{array}{l}\text { Pengembangan Kabupaten Pegunungan Arfak sebagai } \\
\text { daerah pariwisata }\end{array}$ & 0.10 & 2.68 & 0.26 \\
$\begin{array}{l}\text { Terhubungannya berbagai kota di Papua Barat dengan jalan } \\
\text { trans Papua membuka jalur tata niaga antar kota }\end{array}$ & 0.09 & 2.62 & 0.25 \\
$\begin{array}{l}\text { Fenomena teknologi } \\
\text { Persaingan antar peternak }\end{array}$ & 0.11 & 3.18 & 0.36 \\
$\begin{array}{l}\text { Kondisi ekonomi masyarakat } \\
\text { Masuknya stok daging sapi dari luar Kabupaten Pegaf }\end{array}$ & 0.10 & 2.92 & 0.30 \\
$\quad$ untuk memenuhi kebutuhan permintaan konsumen & 0.11 & 3.1 & 0.21 \\
Permainan harga produk ternak & & & \\
\hline$\quad$ TOTAL & 0.10 & 2.86 & 0.29 \\
\hline
\end{tabular}

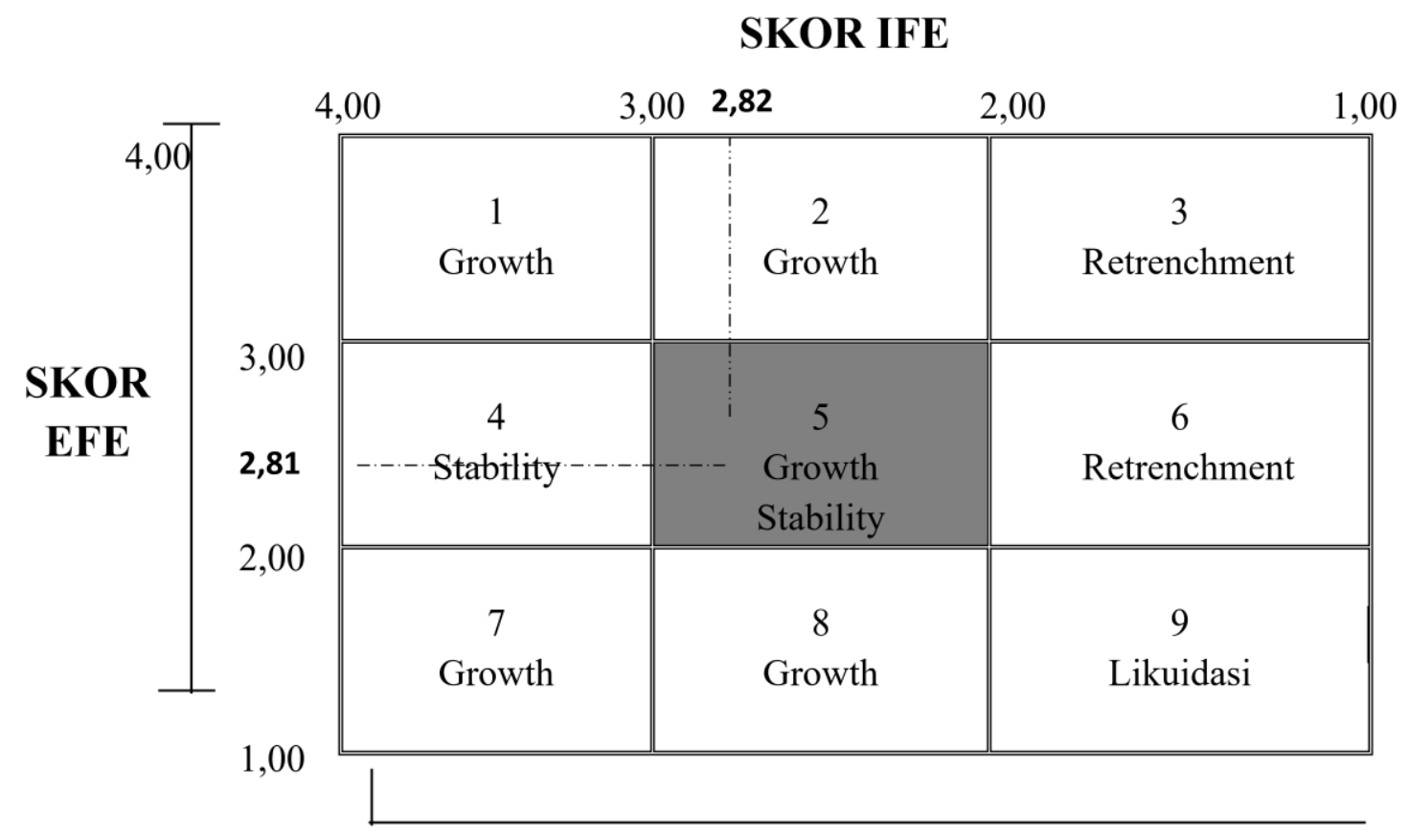

Gambar 1. Diagram matrik IE

\section{Matriks EFE}

Matriks EFE digunakan sebagai evaluasi terhadap peluang dan ancaman yang dimiliki dalam strategi pemasaran ternak sapi potong di Kabupaten Pegunungan Arfak Papua Barat.

Total skor faktor internal sebesar 2,82 dan total skor faktor eksternal sebesar 2,81. Hal ini menunjukkan bahwa pengembangan ternak sapi potong di Kabupaten Pegunungan Arfak Papua berada pada posisi pertumbuhan dan stabil $(2,00-2,99)$ dalam merespon kekuatan dan peluang serta meminimalkan kelemahan dan ancaman eksternal. Hal ini sesuai dengan pendapat Rangkuti (2008), bahwa total skor IFE dan EFE dari skor 2,00 hingga 2,99 menunjukkan bahwa posisi pertumbuhan dan stabil. 


\section{Matriks IE (Internal-Eksternal)}

Matriks IE didasarkan pada dua dimensi kunci yaitu, total skor matriks IFE pada sumbu $\mathrm{x}$ dan total skor matriks EFE pada sumbu y. Matriks IE (Gambar 3) dapat mengidentifikasi 9 sel strategi dan dapat dikelompokkan menjadi strategi utama, yaitu growth strategy, stability strategy dan retrenchment strategy.

Menurut Rangkuti (2008), bahwa total skor berbobot untuk IFE maupun EFE adalah :

$$
\begin{array}{lll}
\text { - } & \text { Kuat } & : 3,00-4,00 \\
\text { - } & \text { Rata-rata } & : 2,00-2,99 \\
\text { - } & \text { Lemah } & : 1,00-1,99
\end{array}
$$

\section{Perumusan Matriks SWOT} (Strengths, Weaknesses, Opportunities, Threats)

Matriks SWOT digunakan untuk merumuskan alternatif strategi pengembangan ternak sapi potong di Kabupaten Pegunungan Arfak Papua Barat dengan memadukan faktor internal dan eksternal, hasil dari tahap input matrik IFE dan EFE yang dapat dilihat pada gambar 4 .

Diagram matriks SWOT pemasaran usaha ternak sapi potong di Kabupaten Pegunungan Arfak Papua Barat adalah

1. Strategi SO adalah strategi yang difokuskan dalam menggunakan kekuatan untuk memanfaatkan peluang. Beberapa strategi SO yang dirumuskan adalah :

a. Memperluas pangsa pasar sapi potong $(\mathrm{O} 1, \mathrm{O} 2, \mathrm{O} 3$; $\mathrm{S} 1, \mathrm{~S} 2$, S3)

b. Meningkatkan kualitas hasil ternak sapi potong $(\mathrm{O} 1, \mathrm{O} 2$; S3)

c. Memperkuat permodalan agar dapat bersaing $(\mathrm{O} 1, \mathrm{O} 2, \mathrm{O} 3$; $\mathrm{S} 1, \mathrm{~S} 2)$
2. Strategi WO adalah strategi yang difokuskan pada bagaimana meminimalkan kelemahan untuk memanfaatkan peluang. Beberapa strategi WO yang dapat dirumuskan adalah :
a. Meningkatkan volume penjualan $(\mathrm{O} 1, \mathrm{O} 2, \mathrm{O} 3$; W1, W2, W3)

b. Menyediakan informasi dalam meningkatkan penjualan (O1, $\mathrm{O} 2$; W1, W2, W3)
c. Mengembangkan peternakan berbasis sumberdaya ternak lokal (O1, O3 ; W1, W2, W3)

3. Strategi ST adalah strategi yang difokuskan pada bagaimana meminimalkan kelemahan untuk menghindari ancaman. Beberapa strategi ST yang dapat dirumuskan adalah :
a. Melakukan pembinaan usaha ternak sapi potong $(\mathrm{T} 1, \mathrm{~T} 2, \mathrm{~T} 3$; $\mathrm{S} 1, \mathrm{~S} 2, \mathrm{~S} 3$ )
b. Meningkatkan pelayanan dalam pemasaran ternak sapi (T2,T3; S1,S3)
c. Menciptakan situasi kondusif dalam pemasaran ternak sapi potong $(\mathrm{T} 2, \mathrm{~T} 3 ; \mathrm{S} 3)$

4. Strategi WT adalah strategi yang difokuskan pada bagaimana meminimalkan kelemahan dan menghindari ancaman. Beberapa strategi WT yang dapat dirumuskan adalah :
a. Menyusun sistem informasi pemasaran ternak sapi potong (T1,T2,T3 ; W1,W2,W3)
b. Meningkatkan kualitas sumberdaya manusia (T1,T3 ; W1,W2)
c. Meningkatkan jaringan kemitraan $(\mathrm{T} 1, \mathrm{~T} 2$ $\mathrm{W} 1, \mathrm{~W} 2, \mathrm{~W} 3$ )




\begin{tabular}{|c|c|c|}
\hline Faktor Eksternal & 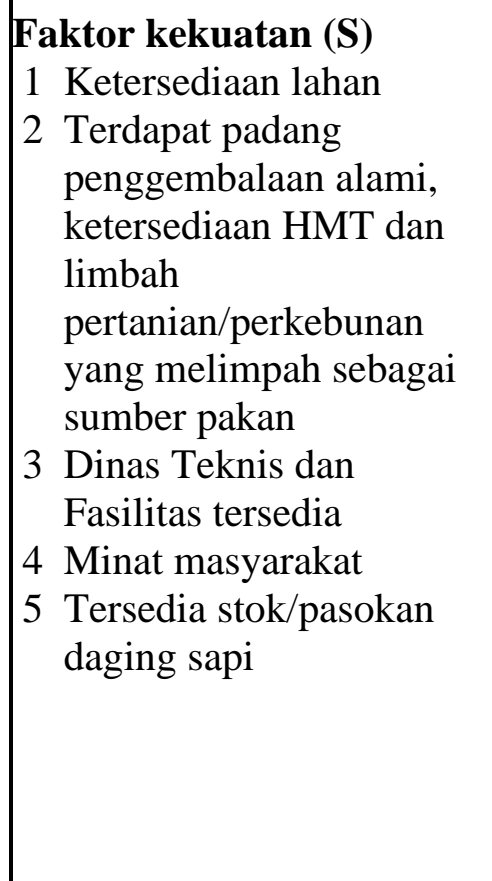 & $\begin{array}{l}\text { Faktor kelemahan }(\mathbf{W}) \\
\text { 1. Peruntukan lahan untuk } \\
\text { kebutuhan lain di luar } \\
\text { subsektor peternakan } \\
\text { 2. Pemanfaatan kepada ternak } \\
\text { kurang, belum dikelola } \\
\text { secara profesional } \\
\text { 3. Petugas kurang, regulasi } \\
\text { teknis peternak belum ada } \\
\text { 4. Tingkat pengetahuan } \\
\text { terbatas. Dan tidak } \\
\text { memiliki proses edukasi } \\
\text { tentang beternak sapi } \\
\text { 5. Konsumen terbatas, jalur } \\
\text { tata niaga masih terpusat di } \\
\text { Kabupaten Pegunungan } \\
\text { Arfak saja, tidak ada } \\
\text { standar harga yang paten. }\end{array}$ \\
\hline $\begin{array}{l}\text { Faktor peluang }(\mathbf{O}) \\
\text { 1. Kebutuhan } \\
\text { masyarakat akan sapi } \\
\text { potong } \\
\text { 2. Daya tawar pembeli } \\
\text { 3. Fenomena sosial } \\
\text { budaya dan } \\
\text { demografi } \\
\text { 4. Pengembangan } \\
\text { Kabupaten } \\
\text { Pegunungan Arfak } \\
\text { sebagai daerah } \\
\text { pariwisata } \\
\text { 5. Terhubungannya } \\
\text { berbagai kota di } \\
\text { Papua Barat dengan } \\
\text { jalan trans Papua } \\
\text { membuka jalur tata } \\
\text { niaga antar kota }\end{array}$ & 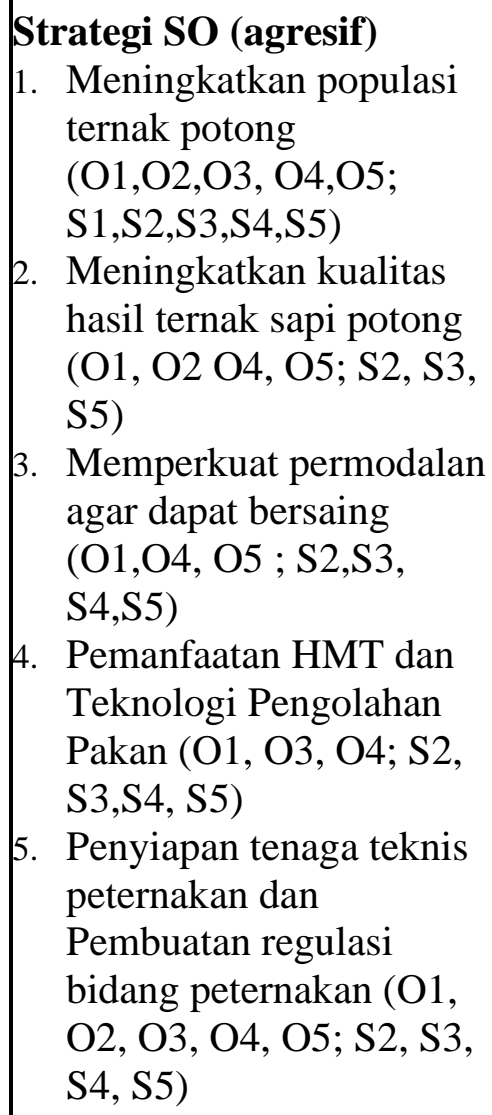 & 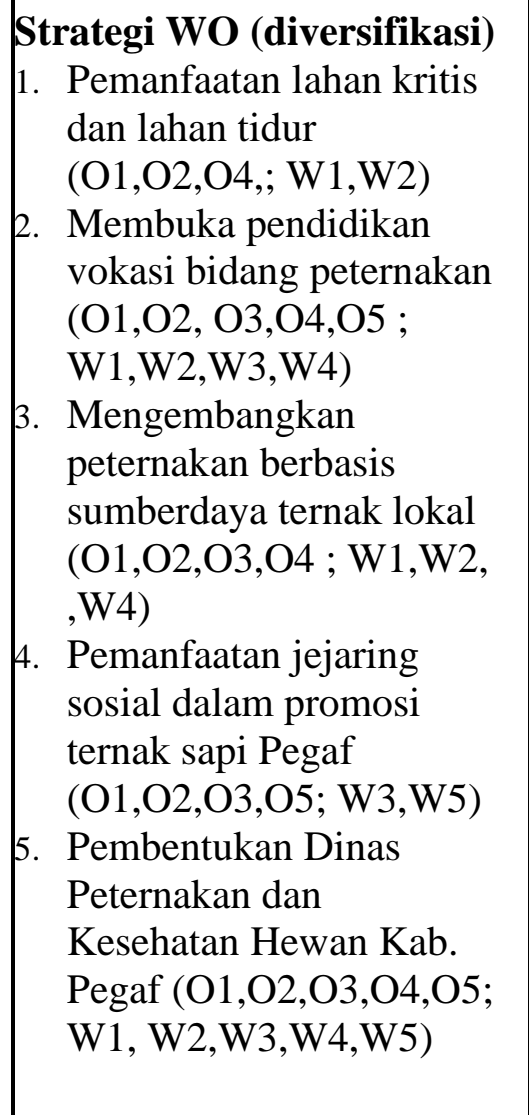 \\
\hline
\end{tabular}




\begin{tabular}{|c|c|c|}
\hline $\begin{array}{l}\text { Faktor ancaman }(\mathbf{T}) \\
\text { 1. Fenomena teknologi } \\
\text { 2. Persaingan antar } \\
\text { peternak } \\
\text { 3. Kondisi ekonomi } \\
\text { masyarakat } \\
\text { 4. Masuknya stok } \\
\text { daging sapi dari luar } \\
\text { Kabupaten Pegaf } \\
\text { untuk memenuhi } \\
\text { kebutuhan } \\
\text { permintaan } \\
\text { konsumen } \\
\text { 5. Permainan harga } \\
\text { produk ternak }\end{array}$ & \begin{tabular}{|l} 
Strategi ST (diferensiasi) \\
1. Melakukan pembinaan \\
usaha ternak sapi potong \\
(T1,T2,T3 ; S1,S2,S3) \\
2. Meningkatkan pelayanan \\
dalam pemasaran ternak \\
sapi (T2,T3 ; S1,S3) \\
3. Menciptakan situasi \\
kondusif dalam \\
pemasaran ternak sapi \\
potong (T2,T3; S3) \\
4. Peningkatan penyuluhan \\
beternak sapi dan sekolah \\
lapang (T1,T2,T3,T4,T5; \\
S2, S3, S4) \\
5. Memaksimalkan \\
teknologi tepat guna \\
bidang peternakan \\
(T1,T3,T4; S1,S3, S4,S5)
\end{tabular} & $\begin{array}{l}\text { Strategi WT (defensif) } \\
\text { 1. } \text { Menyusun sistem informasi } \\
\text { pemasaran ternak sapi } \\
\text { potong (T1,T2,T3; } \\
\text { W1,W2,W3) } \\
\text { 2. } \text { Meningkatkan kualitas } \\
\text { sumberdaya manusia } \\
\text { (T1,T3; W1,W2) } \\
\text { 3. Meningkatkan jaringan } \\
\text { kemitraan (T1,T2; } \\
\text { W1,W2,W3) } \\
\text { 4. Melakukan pola gaduhan } \\
\text { ternak sapi potong } \\
\text { (T1,T2,T3,T5; } \\
\text { W1,W2,W3,W4,W5) } \\
\text { 5. Mengintroduksi HMT } \\
\text { berkualitas ke Pegaf } \\
\text { (T1,T2,T3; W1, W2,W3, } \\
\text { W4,W5) }\end{array}$ \\
\hline
\end{tabular}

Gambar 2. Rumusan strategi pemasaran dengan matriks SWOT

Rekapitulasi hasil perhitungan kekuatan, kelemahan, peluang dan ancaman

Berdasarkan hasil perhitungan yang telah dilakukan, maka didapatkan nilai akhir dari faktor-faktor internal yaitu kekuatan dan kelemahan, serta faktor-faktor eksternal yaitu peluang dan ancaman, seperti pada Tabel 5.

Berdasarkan hasil rekapitulasi pada Tabel 5 diatas, maka strategi keseluruhan dapat diketahui dengan menggunakan peluang sebaik-baiknya, mencoba meminimalisir kelemahan, menggunakan tingkat kekuatan sebagai modal utama dasar serta menekan ancaman yang ada pada pemasaran ternak sapi potong di Kabupaten Pegunungan Arfak Papua Barat.

Tabel 5. Rekapitulasi IFE dan EFE

\begin{tabular}{llc}
\hline No. & \multicolumn{1}{c}{ Uraian } & Nilai \\
\hline 1. & Faktor Internal & \\
& Kekuatan & 1 \\
& Kelemahan & 1,84 \\
2. & Faktor Eksternal & \\
& Peluang & 1,31 \\
& Ancaman & 1,5 \\
\hline
\end{tabular}

Berdasarkan Tabel 5, maka disusun prioritas strategi berdasarkan kombinasi strategi yang memiliki nilai paling tinggi sampai paling rendah, sebagaimana yang terdapat pada Tabel 6. 
Tabel 6. Urutan alternatif strategi SWOT

\begin{tabular}{clc}
\hline Prioritas & \multicolumn{1}{c}{ Strategi } & Bobot Nilai \\
\hline 1 & Strength - Opportunity (SO) & 2,31 \\
2 & Strength - Threat (ST) & 2,5 \\
3 & Weaknesses - Opportunity (WO) & 3,15 \\
4 & Weaknesses - Threat (WT) & 3,34 \\
\hline
\end{tabular}

Berdasarkan Tabel 6 urutan alternatif strategi SWOT, bahwa strategi SO menghasilkan bobot paling tertinggi, dimana strategi ini memanfaatkan seluruh kekuatan untuk merebut dan memanfaatkan peluang yang sebesar besarnya. Strategi SO berdasarkan matrik SWOT memiliki beberapa strategi sebagai berikut:

\section{Memperluas pangsa pasar sapi potong}

Pasar merupakan suatu proses jual beli antara pembeli dan penjual. Pasar menjadi sangat penting dalam pemasaran sapi potong di Kabupaten Pegunungan Arfak Papua. Karena keterbatasan populasi yang ada, permintaan ternak keluar daerah sangat banyak, namun karena keterbatasan, maka kendala peternak dipenuhi oleh setiap pedagang bermodal besar. Tetapi yang paling disenangi adalah dengan perputaran tersebut adanya pasar ternak dari pemerintah daerah khususnya pemerintah Kabupaten Pegunungan Arfak Papua menyiapkan dana talangan untuk membeli sapi potong yang berada di peternak sapi potong. Karena pembelian dalam jumlah yang lebih banyak, pemilihan pola pemasaran tersebut sangat efisien dalam menjual hasil ternak sapi potong dan umumnya dipengaruhi oleh situasi dan kondisi yang ada. Berdasarkan uraian tersebur, memperlihatkan bahwa di masa yang akan datang komoditi sapi potong memiliki ruang gerak pengembangan yang luas, karena belum adanya dukungan pasar yang potensial berdasarkan penelusuran dari sisi penawaran (supply) dan sisi permintaan (demand). Agar tetap eksis sebagai produsen sapi potong, para peternak harus senantiasa meningkatkan kuantitas dan kualitas sapi yang dihasilkan melalui faktor-faktor produksi secara efisien yaitu efisien secara teknis: penggunaan sistem tata kelola pemeliharaan yang dapat meningkatkan pendapatan peternak sehingga menghasilkan nilai tambah (berat badan ternak) dan waktu yang lebih singkat dan efisien secara harga, melalui penambahan biaya produksi untuk mendapatkan harga jualan produk yang lebih tinggi.

2. Meningkatkan kualitas hasil ternak sapi potong

Salah satu pemasaran sapi potong adalah dengan meningkatkan kualitas hasil ternak sapi potong, yaitu dengan meningkatkan skala usaha yang ada, dengan memacu produksi anakan sapi potong baik dari anakan langsung ataupun membeli anakan dari luar daerah. Keunggulan dari wilayah Kabupaten Pegunungan Arfak yang masih tersedianya pakan alami, hal ini dapat meningkatkan kualitas daging sapi potong. Sehingga dapat menambah berat tumbuh sapi secara cepat, sehingga memberikan keuntungan bagi peternak sapi potong, karena pakan alami tidak terlalu banyak dalam mengeluarkan biaya. Pemberian pakan dan nutrisi pada sapi potong sangat berpengaruh terhadap perkembangan sapi potong yang siap dijual. 
3. Memperkuat permodalan agar dapat bersaing

Meningkatkan skala usaha di tingkat peternak dengan memanfaatkan peran lembaga keuangan yang ada di Kabupaten Pegunungan Arfak Papua. Lembaga keuangan yang ada di Kabupaten Pegunungan Arfak memberikan fasilitas kemudahan berupa kredit lunak dengan prosedur sederhana yang dapat dimanfaatkan peternak untuk meningkatkan skala usaha sehingga menjadi lebih efisien. Misalnya dengan menambah jumlah sapi potong sehingga mendekati komposisi ternak yang memberikan keuntungan optimal. Hal ini sesuai dengan Barokah (2009), yaitu meningkatkan dan mengoptimalkan peran kelembagaan keuangan yang telah ada untuk memperbaiki manajemen pengelolaan sapi oleh peternak.

\section{Analisis Strategi QSPM (Quantitative Strategic Planning Matrix)}

Tahap pengambilan keputusan adalah tahap untuk menentukan daftar prioritas alternatif strategi yang paling prioritas untuk diimplementasikan. Matriks perencanaan strategis kuantitatif QSPM merupakan teknik yang secara objektif dapat menetapkan alternatif strategi yang paling prioritas untuk diimplementasikan. Prioritas alternatif strategi ditentukan dengan melihat tingkat Total Nilai Daya Tarik (Total Attractiveness Score/TAS). Penentuan strategi prioritas dilakukan berdasarkan hasil alternatif strategi yang dihasilkan dari matriks SWOT yang ada dengan analisis matriks QSP.
1. Memperluas pangsa pasar sapi potong
2. Meningkatkan kualitas hasil ternak sapi potong
3. Memperkuat permodalan agar dapat bersaing

4. Meningkatkan volume penjualan

5. Menyediakan informasi dalam meningkatkan penjualan

6. Mengembangkan peternakan berbasis sumberdaya ternak lokal

7. Melakukan pembinaan usaha ternak sapi potong

8. Meningkatkan pelayanan dalam pemasaran ternak sapi potong

9. Menciptakan situasi kondusif dalam pemasaran ternak sapi potong

10. Menyusun sistem informasi pemasaran ternak sapi potong

11. Meningkatkan kualitas sumberdaya manusia

12. Meningkatkan jaringan kemitraan

Berdasarkan perhitungan matriks QSPM, ada 3 (tiga) prioritas alternatif strategi yang akan dimplementasikan dan yang paling tepat dimplementasikan, yaitu (1) memperkuat permodalan agar dapat bersaing, (2) Memperluas pangsa pasar sapi potong dan (3) Meningkatkan kualitas hasil ternak sapi potong. Hasil ini sesuai dengan hasil strategi SWOT dimana strategi SO memiliki skor tertinggi diantara strategi yang lain, hanya saja yang menjadi prioritas adalah memperkuat permodalan agar dapat bersaing dengan skor 5,72.

\section{KESIMPULAN DAN SARAN Kesimpulan}

Faktor-faktor

yang mempengaruhi pengembangan sapi potong antara lain : faktor internal yang terdiri dari Ketersediaan lahan, adanya padang penggembalaan alami, ketersediaan HMT dan limbah pertanian/perkebunan yang melimpah sebagai sumber pakan, dinas teknis dan fasilitas tersedia, minat masyarakat, tersedia stok/pasokan daging sapi, peruntukan lahan untuk kebutuhan lain 
di luar subsektor peternakan, pemanfaatan kepada ternak kurang/belum dikelola secara profesional, petugas kurang, regulasi teknis peternakan belum ada, tingkat pengetahuan terbatas dan tidak memiliki proses edukasi tentang beternak sapi, konsumen terbatas, jalur tata niaga masih terpusat di Kabupaten Pegunungan Arfak saja dan tidak ada standar harga yang paten. Sedangkan faktor eksternal antara lain : kebutuhan masyarakat akan sapi potong, daya tawar pembeli, fenomena sosial budaya dan demografi, pengembangan Kabupaten Pegunungan Arfak sebagai daerah pariwisata, terhubungnya berbagai kota di Papua Barat dengan jalan trans Papua membuka jalur tata niaga antar kota, fenomena teknologi, persaingan antar peternak, kondisi ekonomi masyarakat, masuknya stok daging sapi dari luar Kabupaten Pegunungan Arfak untuk memenuhi kebutuhan permintaan konsumen, dan permainan harga produk ternak. Total skor faktor internal sebesar 2,82 dan total skor faktor eksternal sebesar 2,81. Hal ini menunjukkan bahwa pemasaran ternak sapi potong di Kabupaten Pegunungan Arfak berada pada posisi pertumbuhan dan stabil dalam merespon kekuatan dan peluang serta meminimalkan kelemahan dan ancaman eksternal.

Skala usaha pemeliharaan dan pemasaran yang tepat antara lain : meningkatkan kualitas hasil ternak sapi potong, memperkuat permodalan agar dapat bersaing, menyediakan informasi dalam meningkatkan penjualan, mengembangkan peternakan berbasis sumberdaya ternak lokal, melakukan pembinaan usaha ternak sapi potong, menciptakan situasi kondusif dalam pemasaran ternak sapi potong, menyusun sistem informasi pemasaran ternak sapi potong, meningkatkan kualitas sumberdaya manusia dan meningkatkan jaringan kemitraan. Alternatif strategi adalah sebagai berikut a) memperkuat permodalan agar dapat bersaing, b) memperluas pangsa pasar sapi potong dan c) meningkatkan kualitas hasil ternak sapi potong. Perlu adanya perhatian dari Pemerintah Kabupaten Pegunungan Arfak dalam membentuk sentra dan wilayah pengembangan sapi potong. Penambahan fasilitas pendukung pengembangan ternak sapi potong terutama wilayah sentra dan wilayah pengembangan. Peningkatan pengetahuan dan keterampilan peternak melalui penyuluhan dan pelatihan.

\section{DAFTAR PUSTAKA}

Adinata, K.I., A.I. Sari dan E.T. Rahayu. 2012. Strategi Pengembangan Usaha Sapi Potong di Kecamatan Mojolaban Kabupaten Sukoharjo. Tropical Animal Husbandry. 1(1): 24 -32.

Arbi, P. 2009. Analisa Kelayakan dan Strategi Pengembangan Usaha Ternak Sapi Potong - Studi Kasus: Desa Jati Kesuma, Kecamatan Namo Rambe, Kecamatan Deli Serdang. Skripsi. Universitas Sumatera Utara. Medan.

BPS Provinsi Papua Barat. 2014. Papua Barat Dalam Angka. Manokwari.

Hardjosubroto, W. 1994. Aplikasi Pemuliabiakan Ternak di Lapangan. Jakarta: PT Gramedia Widiasarana Indonesia.

Pusat Penelitian Pemberdayaan Fiskal dan Ekonomi Daerah (P3FED) UNIPA. 2012. Kajian Pengembangan Agribisnis Hortikultura Dataran Tinggi Pegunungan Arfak Kabupaten Manokwari. Manokwari.

Sugiyono. 2004. Statistika untuk Penelitian. Bandung. Alfabeta. 
Talib, C.K., Entwistle, A. Siregar, S. Budiartiturner and D. Lindsay. 2003. Survey of Population and Production Dynamics of Bali Cattle and Existing Breeding Program in Indonesia. Hal: 3 9. Entwistle, K. And Lindsay, D.R. 2003. Strategies to Improve Bali Cattle in Eastern Indonesia. Proceeding of Workshop $4-7$ February 2002, Bali, Indonesia. ACIAR Proceedings No. 110, $100 \mathrm{pp}$.

Warwick, E.J., J.M. Astuti dan W. Hardjosubroto. 1995. Ilmu Pemuliaan Ternak. Yogyakarta: Gadjah Mada University Press.

Yulianto, P dan C. Saparinto. 2011. Penggemukan Sapi Potong Hari per Hari. Penebar Swadaya. Jakarta. 